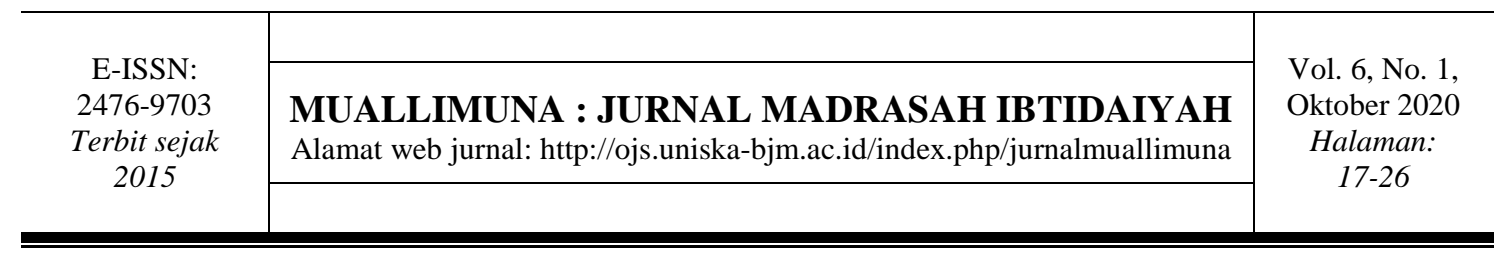

\title{
ANAK DI KELUARGA BERMASALAH: PRESTASI BELAJAR DAN PERKEMBANGANNYA
}

\author{
Roudlotul Jannah ${ }^{1}$, Puji Arianti ${ }^{2}$ \\ ${ }^{12}$ Program Pascasarjana IAIN Salatiga \\ 1roudlotuljannah0802@gmail.com, 2pujiarianti93@gmail.com
}

\begin{abstract}
Abstrak: Kajian ini bertujuan untuk mengetahui prestasi belajar dan perkembangan apa saja yang bermasalah pada siswa MI dan kondisi seperti apa saja di keluarganya sehingga membuat prestasi belajar dan perkembangan anak itu berbeda dari temantemannya. Penelitian kualitatif ini dilakukan di sebuah MI dengan subjek seorang siswa kelas II. Data dikumpulkan dengan menggunakan teknik wawancara, observasi, dan dokumentasi. Temuan kajian ini adalah prestasi belajar siswa tersebut rendah pada aspek kognitif (pengetahuan), afektif (sikap), dan psikomotor (keterampilan). Perkembangan yang bermasalah yaitu pada sosioemosionalnya. Prestasi dan perkembangan yang bermasalah itu disinyalir sebagai akibat dari kondisi keluarga yang melingkupi dirinya, seperti perceraian, orang tua sambung, tidak adanya perhatian dari ayah, ibu yang jarang di rumah, bimbingan bibi yang tidak maksimal. Untuk mencapaian keberhasilan belajar perlu adanya kerja sama yang intensif antara orang tua dan guru dalam mendidik, membimbing, dan mengawasi perkembangan anak.
\end{abstract}

Kata Kunci: keluarga bermasalah, prestasi belajar, perkembangan

\section{CHILD IN A TROUBLED FAMILY: LEARNING ACHIEVEMENT AND DEVELOPMENT}

\begin{abstract}
The research aims to know what problems happen in student's achievement and development then how is the family that influences child's achievement different to others. This qualitative research is conducted to one student in the second grade of elementary school. To collect the data researcher uses interview, observation, and documentation. The finding of this study shows that child's achievement is low in the aspect of cognitive, affective, and psychomotor. The problem of development occurs to the socioemotional. Complicated child's achievement and development allegedly as the effect of family conditions such as divorce, step father, lack of attention from father, mother who is rarely at home, and aunt's assistance that is not optimal. To get success in achievement needs the cooperation between parent and teacher in educating, guiding, and monitoring child's development.
\end{abstract}

Keywords: troubled family, learning achievement, development

\section{PENDAHULUAN}

Pendidikan di Indonesia ditujukan untuk pengembangan potensi peserta didik supaya memiliki kekuatan spiritual keagamaan, pengendalian diri, kepribadian, kecerdasan, akhlak mulia, serta keterampilan yang diperlukan dirinya, masyarakat, 
bangsa, dan Negara. Sebagaimana tercantum dalam pasal 1 ayat 1 UU No. 20 Tahun 2003 tentang Sistem Pendidikan Nasional. Jenis pendidikan diketahui terdiri dari pendidikan formal, informal, dan nonformal. Pendidikan formal, pada pasal 1 ayat 11 , adalah jalur pendidikan yang terstruktur dan berjenjang yang terdiri atas pendidikan dasar, pendidikan menengah, dan pendidikan tinggi. Pendidikan nonformal adalah jalur pendidikan di luar pendidikan formal yang dapat dilaksanakan secara terstruktur dan berjenjang. Pendidikan informal adalah jalur pendidikan keluarga dan lingkungan.

Pendidikan formal dilaksanakan di sekolah atau institusi pendidikan formal. Subjek sentral di dalam jenis pendidikan pertama ini terutama adalah guru. Walaupun demikian, kemajuan pendidikan yang dilaksanakan di dalam pendidikan formal tidak serta merta hanya bergantung pada guru, tetapi juga membutuhkan peran serta orang tua/keluarga dan masyarakat. Keluarga ialah kelompok terkecil dari sosial masyarakat yang meliputi suami/ayah, istri/ibu, dan anak. Keluarga/orang tua mempunyai tanggung jawab, kewajiban, fungsi, dan peran terpenting dalam mendukung perkembangan dan pendidikan anak.

Orang tua mempunyai tanggung jawab dan kewajiban atas anak-anaknya setidaknya dalam tiga hal yaitu: 1) memberi nafkah yang halal. Islam mengajarkan bahwa setiap suami/ayah berkewajiban untuk memberi nafkah kepada istri dan anakanaknya. Hal ini tertera di dalam al-Qur'an surat al-Baqarah ayat 233 yang artinya "Dan menjadi kewajiban para ayah, untuk memberi makanan dan pakaian kepada istri dan anak-anaknya”. 2) memimpin, artinya mengatur dan mengarahkan anak agar menjadi pribadi yang mandiri untuk masa depan kelak. Berkaitan dengan ini orang tua dapat menjadi contoh (teladan) dengan berperilaku baik dan mengajarkan sifat sabar dan jeli (kritis) yang kedua sifat tersebut seharusnya dimiliki oleh seorang pemimpin. Sabda Nabi Muhammad SAW "Setiap kamu adalah pemimpin, dan setiap pemimpin akan dimintai pertanggungjawaban atas apa yang di bawah kepemimpinannya" (HR. Bukhari). 3) mendidik, yang bermaksud untuk menanamkan nilai-nilai karakter sejak dini sebab orang tualah yang berpeluang besar menjadikan anak yang berkarakter baik selain mengantarkannya ke lembaga pendidikan (Ginanjar, 2013).

Kewajiban orang tua di Indonesia atas anaknya ditur dalam pasal 45 UU No 1 tahun 1974 tentang Perkawinan, yaitu kedua orang tua ayah dan ibu) wajib memelihara anak-anak mereka dengan sebaik-baiknya. Kewajiban itu berlaku sampai anak tersebut menikah atau mandiri (dapat berdiri sendiri). Kewajiban terus berlaku walaupun pernikahan antara kedua orang tua telah terputus.

Di samping tanggung jawab dan kewajiban, keluarga juga mempunyai sejumlah fungsi. Menurut Jannah (2018) fungsi keluarga dijabarkan sebagai fungsi sosialisasi dan pendidikan, fungsi cinta kasih, fungsi melindungi, fungsi ekonomi, fungsi keagamaan, fungsi sosial budaya, fungsi reproduksi, dan fungsi pembinaan lingkungan. Sementara itu Rakhmawati (2015) mengemukakan bahwa fungsi keluarga terdiri dari fungsi pendidikan, fungsi perlindungan, fungsi sosialisasi, fungsi kasih sayang, fungsi biologis, fungsi ekonomis, fungsi religius, dan fungsi rekreatif.

Lebih jauh dinyatakan bahwa keluarga diakui berperan penting terhadap perkembangan anak, sebab keluarga adalah lingkungan pertama anak sejak ia dilahirkan. Faktor utama dari orang tua atau keluarga ialah sifat dan keadaan mereka. Dua hal tersebut sangat menentukan arah perkembangan masa depan (future) anak. Yang dimaksud dengan sifat ialah gaya khas dalam melakukan sesuatu (bersikap), memandang, memikirkan, dan memperlakukan anak (Syah, 2004). Di samping itu, secara kuantitatif potensi durasi waktu keberadaan anak saat di lingkungan keluarga 
(family environment) lebih banyak dari pada di sekolah. Bila pada umumnya pembelajaran di SD dilaksanakan selama lima jam, pada 20 jam yang lain anak seringkali bersama anggota keluarga di rumah (16 jam) dan di masyarakat (4 jam).

Keberadaan anak di sekolah yang ternyata lebih sedikit waktunya dari pada di lingkungan keluarga mengimplikasikan perlunya kerja sama yang apik antara guru dan keluarga/orang tua. Wilcox, sebagaimana dikutip oleh Syamsudduha (2017), menyebutkan bahwa partisipasi orang tua untuk menunjang pendidikan anak dapat berbentuk sebagai berikut: 1) pentransfer informasi; 2) mitra konsultasi; 3) membuat keputusan bersama; 4) melakukan tindakan bersama; dan 5) mendukung acara/aktivitas yang timbul atas swakarsa masyarakat. Lebih lanjut Hornby (2011) mengemukakan bahwa bentuk keterlibatan orang tua ada delapan, yaitu:

1. Policy formation (pembentuk kebijakan)

2. Acting as a resource (bertindak sebagai sumber)

3. Collaborating with teachers (kolaborasi dengan guru)

4. Sharing information on children (berbagi informasi kepada siswa)

5. Channels of communication (saluran komunikasi)

6. Liaison with school staff (kerjasama/hubungan dengan staf sekolah)

7. Parent education (pendidikan orang tua)

8. Parent support (dukungan sesama orang tua).

Peran serta keluarga/orang tua dalam mendidik anak ditengarai akan berjalan lancar bilamana keluarga berada dalam situasi dan kondisi normal. Artinya, di keluarga tidak ada masalah yang dapat menghambat proses pendidikan anak. Dengan kata lain, adanya problem dalam suatu keluarga dapat berpotensi mengurangi kelancaran pendidikan anak. Dicontohkan, posisi single parent akibat perceraian menyebabkan seseorang memikirkan ekonomi keluarga dan kebutuhan sehari-hari. Ia pun memerlukan penyesuaian diri menjadi orang tua tunggal. Hal itu berimbas pada kurangnya perhatian terhadap anak sehingga prestasi anak pun menjadi kurang maksimal. Sejumlah kajian telah menghadirkan bukti bahwa permasalahan dalam rumah tangga seperti perceraian dapat mempengaruhi prestasi anak.

Hasil studi yang dilakukan oleh Yusuf (2014) menginformasikan bahwa prestasi belajar anak yang orang tuanya utuh lebih baik dari pada anak yang orang tuanya bercerai. Perceraian orang tua berdampak pada perkembangan jiwa anak dan proses pendidikannya. Suasana keluarga yang terpisah menjadikan kurangnya perhatian orang tua terhadap anak dan menyebabkan anak tidak bisa belajar dengan baik. Pada umumnya anak yang hidup setelah perceraian orang tuanya mengalami perubahan sosio emosional yang berdampak pada kurangnya motivasi belajar sehingga prestasinya rendah.

Kasus serupa menyebutkan bahwa berpisahnya orang tua karena perceraian berpengaruh pada sosio emosional anak. Yang tampak pada diri anak tersebut ialah ekspresi takut dan sedih, malu dan minder, cemas dan tidak percaya diri. Kurangnya perhatian dalam belajar, ia jarang mengerjakan pekerjaan rumah (PR) dari sekolah, sulit berkonsentrasi dalam pembelajaran sehingga banyak mata pelajaran yang belum ia kuasai (Haryanie, Filiani, dan Hanim, 2013).

Dari kajian lain diperoleh hasil bahwa ada seorang anak yang rajin dan pintar. Hal itu ditandai dengan prestasi yang diraih, yakni rangking 3, dan bahkan tahun berikutnya ia mendapat rangking 1. Namun, berangsur-angsur dia gagal mempertahankan pencapaian tersebut. Semenjak perceraian orang tuanya, ia tinggal bersama sang ayah. Pudarnya perhatian orang tua akhirnya berimbas pada rendahnya 
motivasi belajar. Hal itu mempengaruhi proses pendidikannya sehingga prestasinya pun menurun drastis yang ditengarai oleh hasil belajarnya yang tidak maksimal, yakni dia berada di tingkatan 15 besar (Ayuwanty, Mulyana, dan Zainuddin, 2018).

Selaras dengan permasalahan yang dikaji oleh peneliti terdahulu itu, di salah satu MI di Bojonegoro didapati informasi bahwa ada anak kelas II yang prestasi dan perkembangannya bermasalah diduga karena ada permasalahan keluarga. Hasil wawancara dengan guru kelas menyiratkan bahwa prestasi belajar anak tersebut cenderung lebih rendah dari pada siswa lain. Pemenuhan tugas perkembangannya pun berbeda dengan anak-anak lain di kelasnya.

Prestasi belajar diketahui bentuk hasil yang dicapai baik berupa pengetahuan, sikap, maupun keterampilan yang diperoleh setelah melakukan proses belajar. Muhibbin Syah (2004) membahasakan ketiga hasil belajar itu menjadi tiga ranah belajar, yakni ranah cipta (kognitif), ranah rasa (afektif), dan ranah karsa (psikomotor). Masing-masing ranah itu mempunyai indikator yang dapat dipaparkan di Gambar 1.

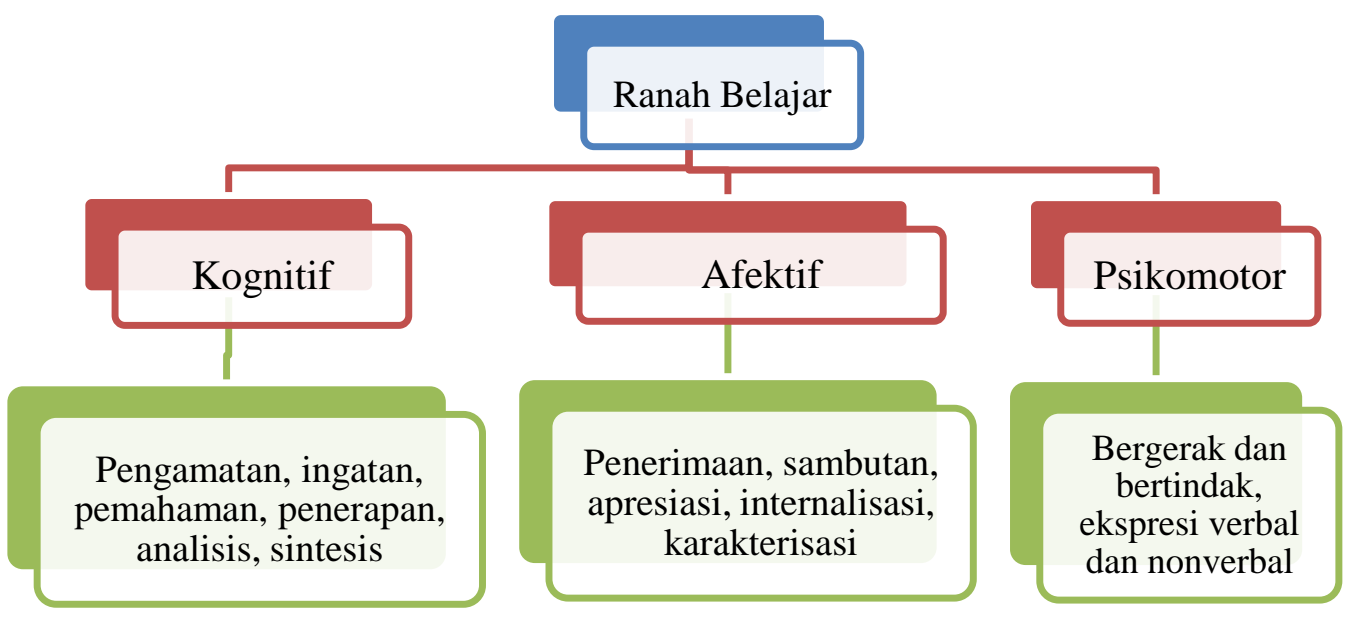

Gambar 1 Jenis Prestasi Belajar (Syah, 2004)

Sementara itu, tugas perkembangan anak usia sekolah dasar adalah menguasai ilmu pengetahuan dan kecakapan intelektual. Hambatan pemenuhan tugas perkembangan pada usia tersebut umumnya adalah inferioritas, tidak produktif, dan tidak kompeten.

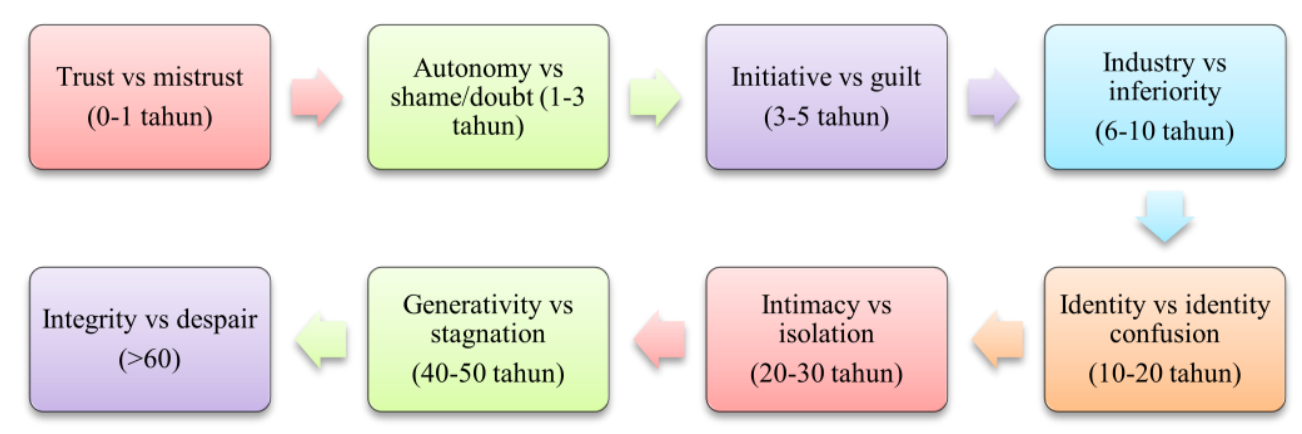

Gambar 2 Tahapan Perkembangan Erikson (Santrock, 2011) 
Pemenuhan tugas perkembangan itu dipengaruhi oleh apa yang disebut oleh Santrock (2011) sebagai "konteks sosial perkembangan". Konteks tersebut meliputi keluarga, teman sebaya, dan sekolah. Menyitir ungkapan Epstein, Santrock mempertegas bahwa keluarga berperan penting dalam mendukung dan menstimulasi pencapaian akademik dan perilakunya di sekolah. Di antara faktor yang berpengaruh adalah gaya pengasuhan, pengasuhan bersama, perubahaan (keadaan) keluarga, dan hubungan keluarga-sekolah. Di samping keluarga, teman sebaya (baik segi usia maupun kedewasaannya) juga berperan penting terhadap perkembangan anak. Di antara fungsi pentingnya adalah sebagai penyedia informasi dan sebagai bahan perbandingan tentang dunia luar selain keluarganya (Santrock, 2011). Selanjutnya perkembangan yang kerap terpengaruh berkat adanya sekolah adalah aspek sosial emosional anak. Dicontohkan oleh Thompson dan Goodman bahwa anak yang mempunyai hubungan yang hangat dan positif dengan guru cenderung mempunyai perilaku yang positif pula. Ia lebih antusias mengikuti pembelajaran dan berprestasi lebih di sekolah (Santrock, 2011).

Teori lain yang berkenaan dengan perkembangan anak adalah Teori Ekologi Bronfenbrenner. Menurutnya, ada lima sistem lingkungan yang berpengaruh terhadap perkembangan anak, yakni:

1. mikrosistem, merupakan suatu setting di mana anak paling banyak menghabiskan waktunya, seperti keluarga, teman bermain, guru, dan tetangga;

2. mesosistem, yakni hubungan unsur-unsur yang ada di mikrosistem, seperti keluarga dengan sekolah;

3. eksosistem, yaitu setting lain yang menambah pengalaman anak, seperti karyawan sekolah dan teman orang tua;

4. makrosistem, yakni budaya dan adat-istiadat yang melingkupi anak; dan

5. kronosistem, dimaksudkan sebagai kondisi sosiohostoris saat anak hidup (Santrock, 2011).

Berdasarkan sejumlah latar belakang dan penggalian data dari guru MI di atas maka penelitian tentang prestasi belajar dan perkembangan anak pada keluarga bermasalah ini akhirnya dilakukan. Kajian berfokus pada prestasi belajar dan perkembangan apa saja yang bermasalah pada siswa MI tersebut dan kondisi seperti apa saja di keluarganya sehingga membuat prestasi belajar dan perkembangan anak itu berbeda dari teman-temannya.

\section{METODE}

Penelitian ini memanfaatkan pendekatan kualitatif dengan pengumpulan data berupa wawancara, observasi dan dokumentasi. Guru menjadi sumber data utama pemerolehan data melalui wawancara, sementara dokumen berupa artikel hasil penelitian terkait dan rekaman audiovisual anak menjadi bagian dari pemerolehan data melalui dokumentasi. Penelitian ini sendiri dilaksanakan di sebuah MI di Bojonegoro pada Maret 2020. Teknik analisis data meliputi reduksi data, penyajian data, dan penyimpulan.

\section{HASIL DAN PEMBAHASAN \\ Hasil}

Kehidupan baru dialami oleh seorang anak yang ditinggal ayahnya akibat perceraian sang ayah dan sang ibu. Saat itu dia berada di jenjang Pendidikan Anak Usia Dini (PAUD) tepatnya di Kelompok Bermain (KB). Ketika dia sudah duduk di 
Raudlatul Athfal (RA) atau sejajar dengan Taman Kanak-kanak (TK) kelompok A, ibunya menikah lagi dan dia mempunyai ayah sambung. Dia diajak pindah oleh ibu dan ayah sambungnya ke luar kota karena pekerjaan ayahnya. Setelah selama setahun tinggal di luar kota, ia diajak kembali ke kampung halaman oleh ibunya sementara ayahnya tetap tinggal di luar kota. Dia berlanjut sekolah di kampung dan masuk PAUD di tingkatan RA. Dia mengulang masuk RA A karena perpindahan dari PAUD tempat ia domisili sebelumnya. Setelah dia naik ke RA B, ibunya bercerai untuk yang kedua kalinya. Dia menikmati masa-masa emasnya (golden age) dengan dua kali pergantian ayah karena ibunya menikah dan bercerai dua kali. Saat kajian ini dilakukan, anak tersebut duduk di kelas dua dalam kondisi tinggal bersama ibu dan ayah ketiga. Sayangnya permasalahan berlanjut dengan retaknya hubungan orang tuanya, di mana keadaan terkini ayah dan ibunya yaitu dalam proses perceraian.

Tahun demi tahun tatkala sang anak menjalani pendidikan di sekolah, yakni mulai prasekolah hingga sekolah dasar tahun kedua, ia lalui dengan minim/kurangnya perhatian dari orang tua dan juga dari keluarga sehingga prestasi dan perkembangannya menjadi terhambat. Diketahui bahwa sejauh ini belum ada dukungan dari pihak orang tua dan keluarga untuk memperbaiki prestasi atau mengejar ketertinggalan perkembangan sang anak dari teman sekelas. Hal ini menjadikan guru bertindak ekstra dalam menangani kasus ini. Buku yang seharusnya dipelajari anak-anak usia RA baru ia pelajari, padahal seusia dia (10 tahun) pada umumnya sudah berada di kelas empat sekolah dasar. Dengan kata lain, secara kuantitatif usianya lebih tinggi dibandingkan teman-teman sekelas namun secara kualitatif kemampuannya amat berbeda dari mereka.

Sesuai informasi dari guru kelas, hasil belajar anak belum maksimal di semua aspek. Aspek yang paling menonjol yang belum dikuasai ialah membaca dan menulis. Kecakapan anak pada dua keterampilan berbahasa itu tergolong lebih rendah dari teman sekelasnya. Usaha yang telah dilakukan sekolah antara lain yaitu dengan memberikan bimbingan khusus. Guru mengajari membaca dan menulis saat teman-teman atau siswa lain sedang mengerjakan tugas. Saat anak tersebut menerima tugas, guru bertindak dengan membacakan soal dan ia menjawab dengan tulisan atas bantuan guru yang mendikte huruf demi huruf. Kadangkala jika anak tersebut mengalami kesulitan dalam menjawab, guru memberi soal yang lebih mudah sesuai dengan kemampuannya.

Dalam hal perkembangan bahasa, guru kelas memaparkan bahwa ia mengalami keterlambatan khususnya pada membaca kata dan kalimat. Pencapaian anak itu baru pada tahap "'bunyi" dan "suku kata". Guru pun tidak berhenti membimbingnya untuk membaca. Anak dilatih untuk mengucapkan "bunyi" kata per kata, misalnya "a-b-c-" dan terkadang masih belum bisa membedakan antara "b" dengan "d" dan antara "k" dengan "x". Per suku kata pun dia pelajari dari awal seperti "da-di", "du-de". Dalam upaya menguasai kemampuan menulis, guru membelajarkan dengan pendiktean untuk menulis huruf, suku kata, atau bahkan kalimat dengan huruf per huruf.

Anak tersebut mengalami kesulitan tidak hanya pada saat pembelajaran, tetapi sosialisasi dengan teman pun kurang maksimal. Dia ditengarai mengalami perkembangan emosional yang kurang baik. Sikap yang tampak selama ini ialah kurangnya kemampuan mengontrol diri saat berinteraksi dengan teman. Hal itu diindikasikan dengan keadaan anak yang mudah tersinggung. Sebagai contoh, ketika ada teman yang melihatnya sambil tersenyum dia menilai teman itu meledeknya dan ketika anak itu bernyanyi lalu ditirukan temannya dia lekas marah. Lebih jauh lagi, saat ada teman yang menasehati ketika dia melakukan kesalahan dia justru "main tangan". Situasi emosional lain terjadi saat ia berada di lingkungannya, ia lekas menangis ketika 
ada teman lebih muda yang menggodanya saat bermain bersama.

\section{Pembahasan}

Keadaan anak yang seperti itu semakin membuatnya berbeda dengan temantemannya, mengingat dia belum bisa memahami situasi kapan saat teman bercanda dan kapan saat berbicara serius. Apabila masalah tersebut tidak segera tertangani, ada posibilitas interaksi sosialnya menjadi terhambat, dan kemungkinan terburuk ia akan teralienasi, padahal usia sekolah dasar diketahui sebagai masa di mana anak mulai bersosialisasi banyak dengan teman dan guru (Slavin, 2000).

Jika mengamati kondisi anak, secara fisik perkembangannya berlangsung seperti anak pada umumnya meskipun orang tuanya telah bercerai. Kebutuhan biologisnya tercukupi karena perekonomian keluarga ditopang oleh kakek dan neneknya. Namun demikian, anak tersebut secara psikis tertekan dengan keadaan yang dialami oleh keluarganya. Kurangnya kasih sayang dan perhatian dari orang tua disinyalir menjadi penyebab perkembangan dirinya yang belum maksimal. Terlebih dengan keadaan orang tua yang sudah berpisah. Sejak usia dini hingga usia sekolah ia dihadapkan dengan masalah-masalah orang tuanya. Dikarenakan usianya yang masih kanak-kanak, ia belum bisa berargumen ataupun berontak dengan situasi sedemikian rupa. Kondisi seperti itu membuat batinnya terpengaruh sehingga meluap ke dalam perilaku dan sikapnya sehari-hari.

Berdasarkan penjelasan dari guru, setelah perceraian orang tua ia tinggal bersama ibunya. Ibunya berperan ganda yakni sebagai ibu sekaligus ayah baginya karena ibunyalah yang mencari nafkah demi mencukupi kebutuhan hidup sehari-hari. Ibunya pun sampai harus bekerja di luar daerah. Hal demikian membuat kurangnya kualitas kebersamaan antara orang tua dan anak. Ayahnya yang tidak diketahui keberadaannya sama sekali tidak memikirkan kehidupan anaknya, bahkan sekedar menanyakan kabar pun tidak dilakukan. Perhatian yang hanya didapat dari orang tua tunggal dapat membuat psikis anak berubah. Santrock menyimpulkan beberapa pendapat tentang anak yang hidup setelah perceraian orang tua, di antaranya anak mengalami penyesuaian yang lebih buruk. Efek dari perceraian tergolong kompleks, tergantung beberapa faktor yaitu umur anak, kekuatan dan kelemahan anak saat perceraian orang tua terjadi, jenis pengasuhan, status ekonomi sosial, dan fungsi keluarga setelah perceraian (Santrock, 2011).

Terkait jenis pengasuhan, ibu dari anak tersebut diketahui menerapkan pola asuh permisif (children centered) yakni memberi kebebasan kepada anak, apa yang dia inginkan selalu dipenuhi. Contohnya ketika anak menginginkan mainan, ibu pun mengabulkan permintaan itu. Di samping pola asuh permisif, Ayun mengemukakan dua bentuk lain pola asuh, yakni (1) pola asuh otoriter (parent oriented), pola asuh yang bersifat keras, mengatur, dan memaksa (2) pola asuh demokratis, sejajar antara orang tua dan anak dalam artian kebebasan anak berada dalam pengawasan orang tua (Ayun, 2016). Sementara Baumrind, seperti diulas kembali oleh Santrock, membagi gaya pengasuhan menjadi empat, yakni: (1) authoritarian parenting; (2) authoritative parenting; (3) neglectful parenting; dan (4) indulgent parenting (Santrock, 2011).

Jika dikaitkan dengan tanggung jawab orang tua, anak tersebut hanya mendapat nafkah saja, itupun dalam bentuk lahiriyah. Ia belum cukup memperoleh bimbingan dan didikan dari ibunya. Hafiz \& Noor (2016) mengemukakan bahwa tumbuh kembang anak merupakan pencerminan dari didikan orang tuanya. Jika ia dibesarkan dengan keadaan atau kebiasaan buruk maka akan berpengaruh pada saat ia tumbuh dewasa, dan begitu pula sebaliknya. Tanggung jawab berupa kepemimpinan, arahan, dan pendidikan dari ayahnya pun tidak pernah dirasakan. Kewajiban yang disuratkan di Pasal 45 UU Nomor 1 tahun 1974 
tentang Perkawinan juga tidak dijalankan oleh ayahnya meskipun statusnya telah bercerai dengan sang ibu. Pada akhirnya, fungsi keluarga sebagaimana diulas di muka pun tidak terpenuhi.

Berdasarkan uraian guru dapat dinyatakan bahwa orang tua tunggal anak tersebut (ibu) lebih fokus dengan kesibukannya sendiri, penyesuaian diri, bekerja, sering keluar rumah sehingga perhatian ke anak berkurang dan perkembangan pendidikan anak tidak diprioritaskan. Hal ini dapat dibuktikan bahwa bibinyalah yang menemani anak tersebut belajar. Aktivitas itupun jarang terlaksana karena kesibukan bibinya yang juga bekerja dan menjalani kuliah. Kurangnya perhatian orang tua terhadap anak tersebut berpengaruh pada perkembangan bahasa si anak. Padahal telah dikenal bahwa perkembangan bahasa dipengaruhi oleh dua faktor, yakni gen dan lingkungan (Santrock, 2011; Levine and Munsch, 2016). Hal itu dipertegas oleh pemaparan Yusuf bahwa ada dua faktor yang dapat mempengaruhi perkembangan bahasa, yaitu faktor internal (gen)/nature dan faktor eksternal (lingkungan)/nurture (Latifa, 2017). Fenomena yang terjadi pada anak tersebut dikarenakan oleh faktor lingkungan keluarga yakni kurangnya pendampingan dari orang tua dalam belajar.

Dalam hal pendidikan anak, ibu tersebut berpartisipasi dalam bentuk memberi informasi tentang perkembangan anak saat di rumah dan lingkungan sosial, ibu pun mendukung dan turut andil dalam acara swakarsa masyarakat. Demikian ungkapan dari guru saat guru melaksanakan home visit selama dua kali kunjungan. Bentuk lain yang mengarah ke acara sekolah tidak ada partisipasi karena memang dari pihak sekolah tidak melibatkan orang tua pada momen-momen penting.

Berdasarkan sejumlah temuan dan uraian di atas, prestasi belajar anak kelas II MI tersebut bermasalah pada tiga domain, yakni kognitif (pengetahuan), afektif (sikap), dan psikomotor (ketrampilan). Masalah pada ranah pertama ditandai dengan pemahaman yang kurang saat menerima materi sehingga dalam mengerjakan tugas masih butuh bimbingan guru. Lebih jauh, prestasi kognitif yang kurang maksimal ditandai dengan kesalahan penyebutan huruf dan kesulitan membandingkannya.

Problem pada ranah kedua diindikasikan dengan kurangnya perhatian anak terhadap pembelajaran. Ketika guru memberi tugas, dia berlarian ke luar kelas dan menolak untuk mengerjakan tugas, sehingga dia masih perlu bimbingan pada ranah afektif. Kesulitan menulis dan membaca menjadi contoh indikator permasalahan pada ranah ketiga, yakni pencapaiannya masih pada permulaan, yaitu penulisan dan membaca huruf dan suku kata, sementara sebagian besar temannya telah mencapai lebih dari itu. Padahal dua kemampuan tersebut sebagai modal utama dalam mempelajari seluruh bidang ilmu, sehingga jika seseorang belum menguasai dua kecakapan itu maka akan menghambat proses belajar (Muhyidin, 2016). Di samping itu, tidak semua kegiatan yang bertujuan untuk stimulasi psikomotor anak dapat ia ikuti, karena ia terkadang melaksanakan tugas guru sesuai keinginannya sendiri, alias tidak sesuai instruksi.

Perkembangan anak tersebut juga berbeda dari teman-temannya, antara lain adalah kurang dapat mengendalikan diri, mudah tersinggung dan lekas marah. Perbedaan perkembangan yang dialami anak itu disinyalir sebagai akibat dari sejumlah kondisi keluarga yang melingkupi dirinya, seperti perceraian, orang tua sambung, tidak adanya perhatian dari ayah, ibu yang jarang di rumah, bimbingan orang lain (bibi) yang tidak maksimal.

Fenomena pada anak itu berimplikasi pada perlunya kerja sama intensif antara guru dan orang tua dalam hal mengasuh/mendidik dan mengawasi perkembangan anak. Di antaranya dengan melakukan sesuatu seperti yang ditawarkan oleh Syamsudduha yaitu tindakan bersama, misalnya ketika guru di sekolah mendikte anak dalam pembelajaran 
menulis, orang tua melakukan hal yang sama meluangkan waktu untuk mendikte di rumah. Orang tua sangat berperan bagi pendidikan anak karena dapat mendukung belajar dan menentukan prestasinya. Santrock menyebutkan bahwa semakin kuat keterlibatan orang tua terhadap belajar anak, semakin berpotensi untuk mencapai keberhasilan. Intervensi orang tua dalam belajar anak akan sangat mempengaruhi/menstimulasi kecerdasan anak atau setidaknya dapat memotivasinya sehingga anak merasa terbantu saat belajar (Santrock, 2011). Lebih lanjut dinyatakan ulang oleh Saptono bahwa keterlibatan orang tua dan komunitas (masyarakat) sangat berpengaruh terhadap perkembangan anak (Arifin, 2017).

Merujuk pada penelitian Hetherington bahwa anak korban perceraian memiliki prestasi tinggi ketika pihak keluarga/kedua orang tua dan sekolah bekerja sama untuk membimbing dan mendidik secara otoriter. Apabila hanya satu orang tua yang otoriter, yakni setelah terjadi perceraian, maka pihak sekolah yang lebih mempengaruhi dalam perkembangan anak. Namun kegagalan terjadi bilamana kedua orang tua tersebut tidak ada yang otoriter (Santrock, 2011).

Menciptakan hubungan sosial yang baik seperti mempertalikannya dengan keluarga inti, keluarga besar, teman, dan guru dapat membantu perkembangan sosioemosional anak. Pengajaran nilai-nilai, kebiasaan-kebiasaan baik, dan pemberian dorongan/motivasi dapat dimunculkan dalam hubungan orang tua dengan anak (Sanders and Morawska, 2018). Pengajaran nilai-nilai dapat dicontohkan dengan pembacaan cerita atau kisah-kisah teladan yang syarat akan nilai-nilai pengembangan sosial emosional. Barsihanor (2015) menyebutkan beberapa bentuk atau wujud kerja sama antara orang tua dan guru dapat dilakukan di antaranya 1) memfungsikan buku penghubung guna memantau atau mengontrol perkembangan anak; 2) melakukan home visit, bertujuan untuk memotivasi orang tua dalam hal pendidikan anak dan dalam rangka menyelesaikan permasalahan yang dihadapi siswa; 3) komunikasi via ponsel untuk mempermudah komunikasi orang tua dan guru dalam hal pengawasan terhadap aktivitas anak.

\section{PENUTUP}

Prestasi belajar anak bermasalah pada ranah kognitif, afektif, dan psikomotor. Perkembangan anak tersebut juga berbeda dari teman sekelasnya, seperti kurang dapat mengontrol diri, kerap tersinggung dan lekas marah. Kondisi anak yang sedemikian rupa membuat perlunya kerja sama intensif antara guru dan orang tua dalam hal mendidik anak.

\section{UCAPAN TERIMA KASIH}

Penelitian ini terlaksana berkat keterlibatan beberapa pihak. Oleh karena itu ucapan terima kasih disampaikan kepada orang tua anak dan Kepala MI yang memberikan izin penelitian. Terima kasih juga kepada guru, tenaga kependidikan, dan segenap informan yang berperan dalam pemerolehan data. Jazakumullahu ahsanal jaza'. Aamiin.

\section{DAFTAR PUSTAKA}

Arifin, M. F., (2017). Model Kerjasama Tripusat Pendidikan dalam Pendidikan Karakter Siswa, Muallimuna: Jurnal Madrasah Ibtidaiyah 3 (1), 78-86.

Ayun, Q. (2016). Pendidikan dan Pengasuhan Keluarga dalam Membentuk Perkembangan Kepribadian Anak: Perspektif Psikologi Perkembangan Islam, Attarbiyah, 26, 91-118.

Ayuwanty, F., Mulyana, N., Zainuddin, M. (2018). Prestasi Belajar Anak Dengan Orang 
Tua Tunggal, Jurnal Pekerjaan Sosial, 1 (2), 148-157.

Barsihanor, (2015). Kerjasama antara Sekolah dan Keluarga dalam Pendidikan Karakter, Muallimuna: Jurnal Madrasah Ibtidaiyah, 1 (1), 54-69.

Ginanjar, M. H. (2013). Keseimbangan Peran Orang Tua dalam Pembentukan Karakter Anak, Edukasi Islami Jurnal Pendidikan Islam, 2, 230-242.

Hafiz A., \& Noor, H., (2016). Pendidikan Anak dalam Perspektif Alquran, Muallimuna: Jurnal Madrasah Ibtidaiyah, 1 (2), 112-127.

Haryanie, S. W., Filiani, R., Hanim, W. (2013). Dampak Perceraian Orang Tua terhadap Emosi Anak, Insight: Jurnal Bimbingan dan Konseling, 2 (1), 100-106.

Hornby, G. (2011). Parental Involvement in Childhood Education. London: Springer.

Jannah, M. (2018). Konsep Keluarga Idaman dan Islami, Gender Equality: International Journal of Child and Gender Studies, 4 (2), 87-102.

Latifa, U. (2017). Aspek Perkembangan pada Anak Sekolah Dasar: Masalah dan Perkembangannya, Academica, 1 (2), 186-196.

Levine, L. E. \& Munsch, J. A. (2016). Child Development, SAGE Publications.

Muhyidin, A. (2016). Pembelajaran Membaca dan Menulis Permulaan Bahasa Indonesia di Kelas Awal, BAHTERA: Jurnal Pendidikan Bahasa dan Sastra, 15 (2), 1-12.

Rakhmawati, I. (2015). Peran Keluarga dalam Pengasuhan Anak, KONSELING RELIGI: Jurnal Bimbingan Konseling Islam, 6 (1), 1-17.

Sanders, M. R. \& Morawska, A. (2018). Handbook of Parenting and Child Development Across the Lifespan, Brisbane: Springer.

Santrock, J. W. (2011). Educational Psychology, New York: McGrawHill.

Slavin, E. S. (2000). Educational Psychology, Boston: Allyn and Bacon.

Syah, M. (2004). Psikologi Pendidikan dengan Pendekatan Baru. Bandung: PT Remaja Rosdakarya.

Syamsudduha, St. (2017). Partisipasi Orangtua dalam Pendidikan Anak di Sekolah pada SD IT Al-Fityan Kabupaten Gowa, Jurnal al-Kalam, IX (2), 141-158.

Undang-undang RI Nomor 1 Tahun 1974 tentang Perkawinan.

Undang-undang RI Nomor 20 Tahun 2003 tentang Sistem Pendidikan Nasional.

Yusuf, MY., M. (2014). Dampak Perceraian Orang Tua terhadap Anak, Jurnal AlBayan, 20. (29), 33-44. 